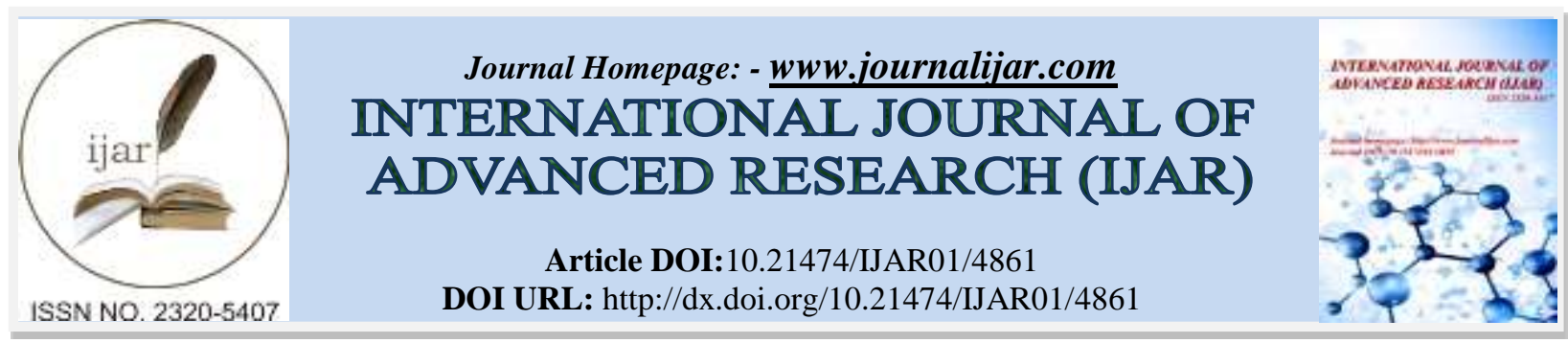

RESEARCH ARTICLE

\title{
COMBINATION EFFECT OF ZIZYPHUS SPINA CHRISTI AND HYPERTHERMIA ON LIVER AND KIDNEY AFFECTED BY EAC IN MICE.
}

Safwat A Okasha, Fawzia M K Takadom and Mohamed K Hassan.

\section{Manuscript Info}

Manuscript History

Received: 15 May 2017

Final Accepted: 17 June 2017

Published: July 2017

\section{Abstract}

Loading mice with EAC affect Functions of vital organs specially Liver and Kidney because of these tissues are severely damaged in the animals with EAC cells. The ability of Zizyphus spina Christi (ZSC) fruit extract when combined with hyperthermia to improve the histopathological features associated with Ehrlich Ascites Carcinoma (EAC) stress in experimental mice was assessed. EAC loading mice were treated with hyperthermia or ZSC fruit extract doses (100, 300 $\mathrm{mg} / \mathrm{Kg} \mathrm{B.W}$ ) or with combination between them once/ two days alternatively, for 14 days. Combination treatment of ZSC fruit extract and hyperthermia significantly improve the damage.

EAC load had increased the activities of serum GOT and GPT but decreased the concentration of albumin and total protein. Different treatment with hyperthermia or ZSC fruit extract or combination reduced the level of sGPT and sGOT but not significantly. A nonsignificant increase in the level of serum albumin and total protein was observed too.

Moreover, levels of the renal biomarkers, creatinine and urea were highly elevated in EAC-bearing mice, urea level increase after different treatments not significantly where creatinin levels had slight affect except in high dose combination treated group.

Taken together, results from this study suggest that addition of ZSC fruit extract to hyperthermia slightly reduce the hepatic and renal damage induced by EAC load in experimental animals.

Copy Right, IJAR, 2017,. All rights reserved.

\section{Introduction:-}

Hyperthermia has been used as one of the therapies for cancer treatment since the early 1970s.It is a therapeutic procedure used to raise the temperature of a region of the body affected by cancer about 6 degrees above body temperature, is elevated to $43^{\circ} \mathrm{C}$, causing the destruction of the tumor mass. Although hyperthermia alone is not very harmful for the normal cells, hyperthermia alone is not potential therapy for breast cancer, however combination with different therapies like radiation or chemotherapy significantly improves the therapeutic outcome.

Despite the wide use of chemotherapy in breast cancer (BC) treatment but current methods such as chemotherapy have their limitations due to their toxic effects on non-targeted tissues causing human health problems (Ochwang'I et al., 2014). Therefore, the chemoprevention with natural phytochemical compounds is highly demanded for alternative treatments emerging strategies to enhance $\mathrm{BC}$ treatment. The use of natural products has been the single most successful strategy in the discovery of novel therapies (Tulp and Bohlin, 2002).Plants provide important 
resources for a large number of natural compounds with anti-tumor activity (Evans, 2002 and Kaur et al., 2011). In recent years, a significant percentage of anti-cancer drugs are in clinical trials that are dependent on natural resources (Cragg et al., 2000).

ZSC belongs to family Rhamnaceae, which is common in the subtropical and tropical regions. ZSC is known in Egypt as 'Nabq' or 'Sidr' (Ta“ckholm, 1974), and it is one of 40 species in Rhamnaceae family characterizes by being small trees and spiny shrubs. Cytotoxic activity of plants from family Rhamnaceae has been shown in several studies (Kaur et al., 2011 and Mervat and Gendy, 2010). ZSC was selected as a research target species because it had been used in alternative medicine for the treatment of fever, pain, dandruff, wounds and ulcers, inflammatory conditions, asthma and to cure eye diseases. Moreover ZSC has recently been shown to have antibacterial, antifungal, antioxidant and anti-hyperglycemic activities (Abalaka et al., 2011). Flavonoids, alkaloids and saponins are the main phytochemical constituents that are reported from this plant (Adzu et al., 2003).However, limited studies have shown that crude extract of ZSC had cytotoxic effect on tumor cell lines.

Liver and kidney tissues come in direct touch with the ascites. Thus, we focused on the liver and kidney tissues and their functions as indicators for recovery from the EAC loading. The histological study confirmed the relative healthy features of the liver and kidney. The present study aimed at evaluating the potency of combination between hyperthermia and ZSC fruit extract to improve the biochemical and histological injuries induced in the liver and kidney by EAC-load in the experimental mice.

Little is known about the effectiveness of combination of hyperthermia and natural phytochemical compounds. Our results may open the gate for further optimization studies to get the best benefits from this combination and introduce preclinical approach to improve breast cancer therapies.

\section{Materials and Methods:- \\ Extract preparation:-}

ZSC fruits were collected from Aswan, Egypt, and dried away from the sun. The extraction occurred through several steps, including, (1) Grinding dried fruits by electrical Miller. (2) Adding solvent (80\% ethanol) to the grinded fruits in a flask, leave them about 2 days. (3) Filtration: using conical and filter paper. (4) Distillation: by using rotary evaporator. Finally, the extract Left days for drying from the excess alcohol and water, thin saved at room temperature. The extract was then prepared for injection by dissolving in $70 \%$ ethanol at concentrations of $(100 \mathrm{mg} / \mathrm{kg})$ for low dose and $(300 \mathrm{mg} / \mathrm{kg})$ for high dose.

\section{Experimental Animals:-}

72 Adult female Swiss albino mice (20-25gm) were obtained from the animal house of the Egyptian Company for Vaccines production, Helwan, Egypt. Mice were acclimatized to the environment prior to the experimental use. They were kept in cages under standard conditions of temperature, pressure and humidity and they were maintained on standard pellet diet and tap water.

EAC-bearing albino mice (tumor donor animals) were obtained from tumor national institute, Cairo, Egypt. Ehrlich tumor cells $\left(2 \times 10^{6}\right)$ were intraperitonealy injected into the normal experimental mice.

\section{Animal grouping:-}

After two days of Ehrlich tumor cell injection, female mice were grouped as follows:

A. Group1; EAC bearing mice, Normal mice were I.P injected with tumor cells.

B. Group2; hyperthermia treated group

C. Group3; low dose ZSC-receiving group (100mg ZSC)

D. Group4; low dose ZSC + hyperthermia-receiving group (100mg ZSC + Hyperthermia)

E. Group5; high dose ZSC-receiving group (300mg ZSC)

F. Group6; high dose ZSC + hyperthermia-receiving group (300mg ZSC + Hyperthermia)

\section{Treatments:-}

Extract treatment:- ZSC ethanolic fruit extract was injected inter peritoneal (i.p) into mice day after day, alternatively with hyperthermia treatment. 
Hyperthermia:-For treating the animals with hyperthermia, adjusted at the $43.5^{\circ} \mathrm{C}$ water bath was used where abdominal part of mice body impeded in water for the desired time (45 - 90 minutes). After two weeks of experiment animals were sacrificed.

\section{Serum biochemical analysis:-}

After the animals were sacrificed, blood from each animal was collected in Eppendorf and centrifuged at $300 \mathrm{rpm}$ for 15 minutes. Biochemical analyses including (sGPT and sGOT activities, Albumin concentration, Total protein, Urea and Creatinine) were determined by colorimetric methods using ready-made kits produced by instrumentation Laboratory SpA, Inova diagnostics, Milano, Italy.

\section{Histological Examination:-}

Parts of liver and kidney tissues obtained from animals were directly fixed in 10\% neutral formalin (PH 7.0), dehydrated in ascending series of ethyl alcohol, and embedded in molten paraffin wax at 58-62 5 . Tissue sections, $5 \mu \mathrm{m}$ in thickness were obtained and stained with Hematoxylin and Eosin and evaluated to study any histological changes in the liver and kidney structures under a bright field microscope.

\section{Statistical Analysis:-}

The data were expressed as mean \pm standard error and were analyzed by means of One-way ANOVA using Minitab software for windows to find if there was any significant difference among control and treated groups. Tabulation and graphics of data were done using Microsoft Exel2010.

\section{Results:-}

\section{Biochemical Assay:-}

Hepatic biomarkers:-

The changes in the serum liver biomarkers are shown in figure $1(\mathrm{~A} \& \mathrm{~B})$. EAC load in albino mice induced hepatotoxicity which is represented as increase in liver biomarkers serum sGOT and sGPT activities. Different treatments with ZSC or with hyperthermia or with combination did not show significant changes in sGOT and sGPT levels as in figure A \& B. Moreover, albumin levels increase in all treated groups not significantly. Total protein levels increase only in low dose treated group and high dose combination treated group not significantly (Figure C\& D).
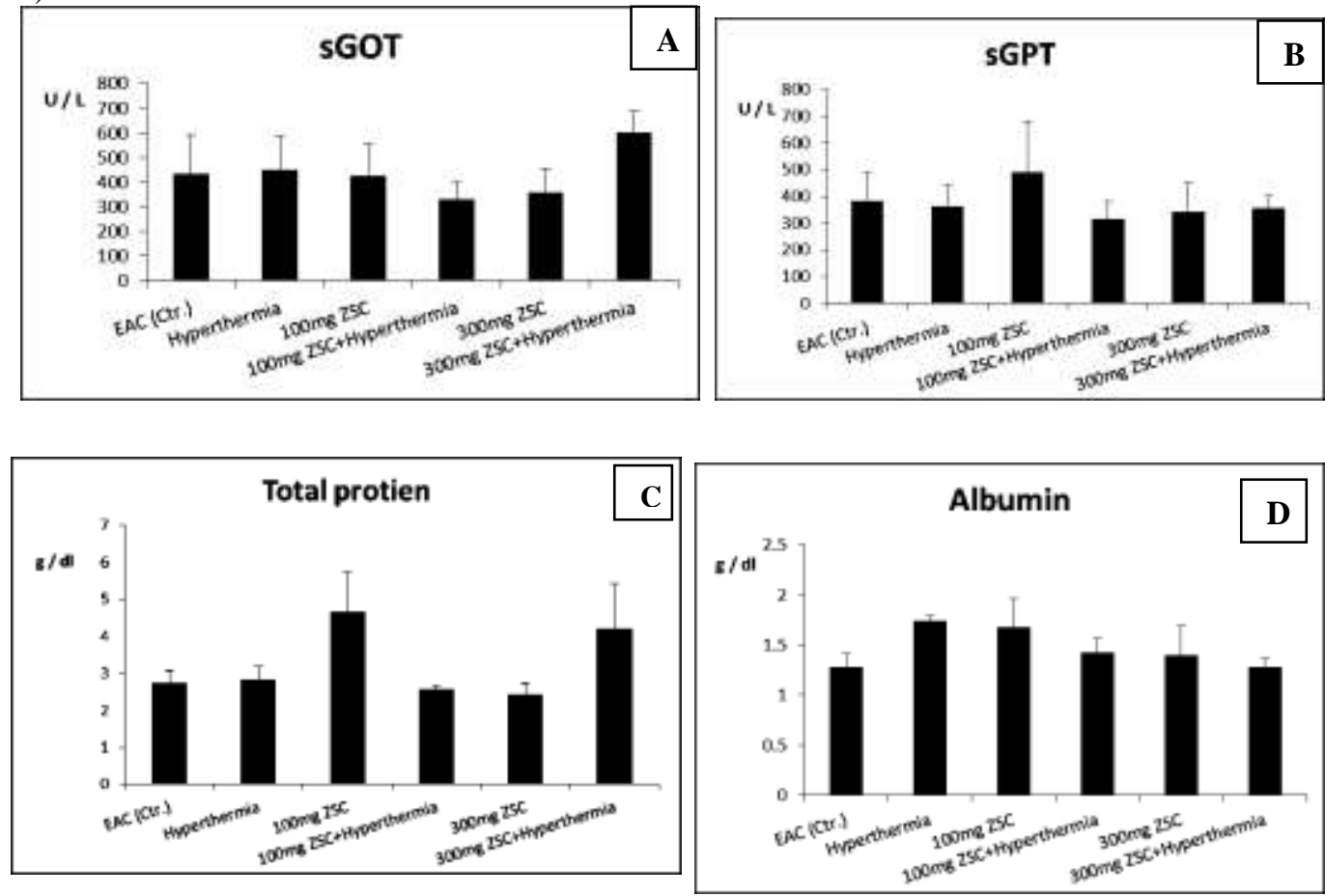

Figure1:-Effect of different treatments of hyperthermia or ZSC or combination on the alteration of liver biochemical markers induced by EAC-load, (A) sGOT, (B) sGPT, (C) total protein and (D) albumin levels. 


\section{Renal biomarkers:-}

EAC-bearing albino mice induced renal damage which is represented as disturbance in renal biomarkers (Urea and Creatinine). As shown in figure 2, treatment of EACs-bearing mice with different treatments caused increase in urea levels significantly in high dose treated group. However, there were no significant changes in creatinine levels as illustrated in figure $\mathbf{2 A}$ and $\mathbf{B}$.

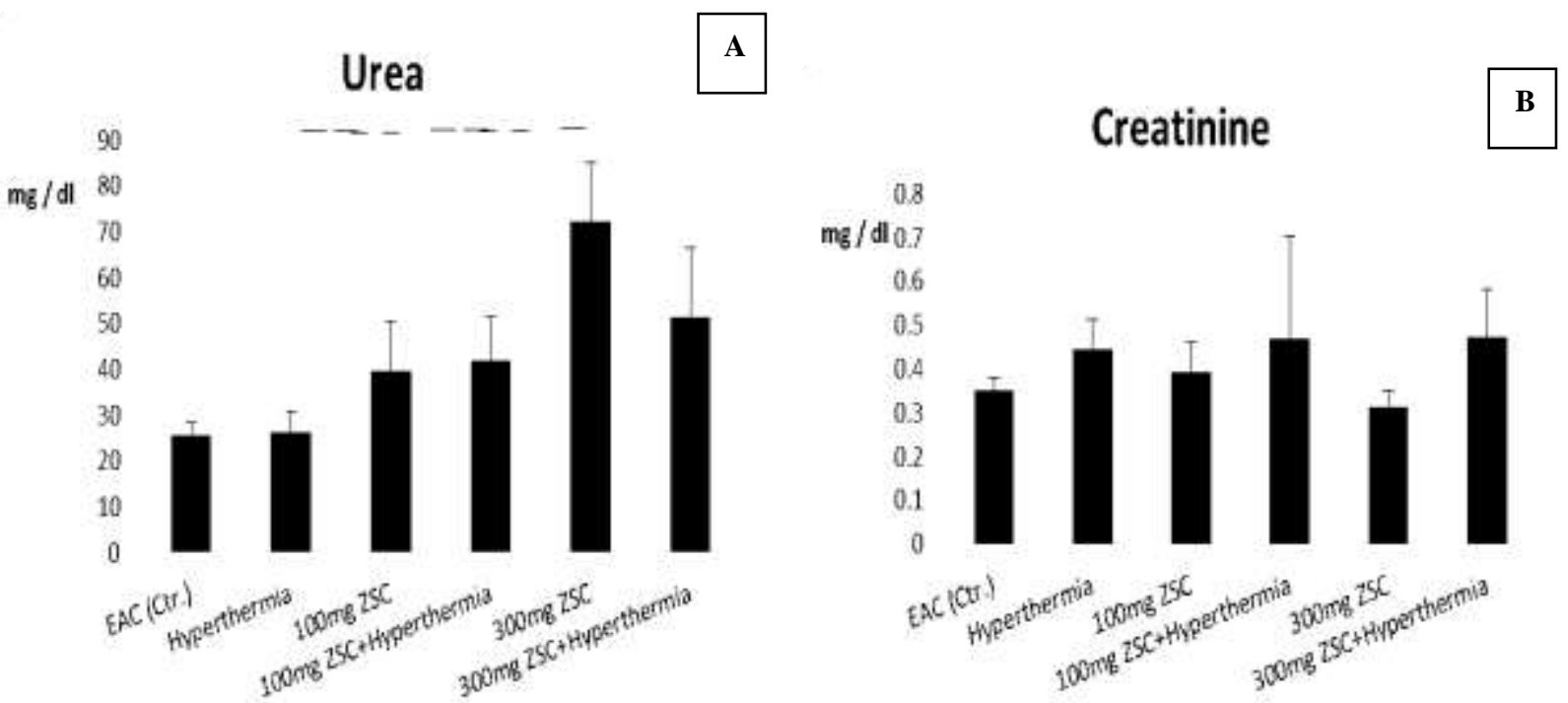

Figure2:- Effect of different treatments of hyperthermia or ZSC extract or combination on the alteration of renal biochemical markers induced by EACs-bearing mice, (A) Urea, (B) Creatinine levels.

\section{Histopathological Assay:-}

Liver sections from EAC-loaded mice and treated mice are shown in figure 3A-3F. Loading mice by EAC showed the proliferation of malignant cells on the surface of the liver and changes in liver cells. Also, kidney sections from EAC-loaded mice and treated mice are shown in figure 4A-4F. Loading mice by EAC showed marked proliferation of malignant cells at surface of kidney tissue showing marked cellularity and pleomorphism. An improvement and decrease of neoplastic cells number on liver and kidney surface in EAC-loaded mice after treatments with combination treatment was clearly observed.
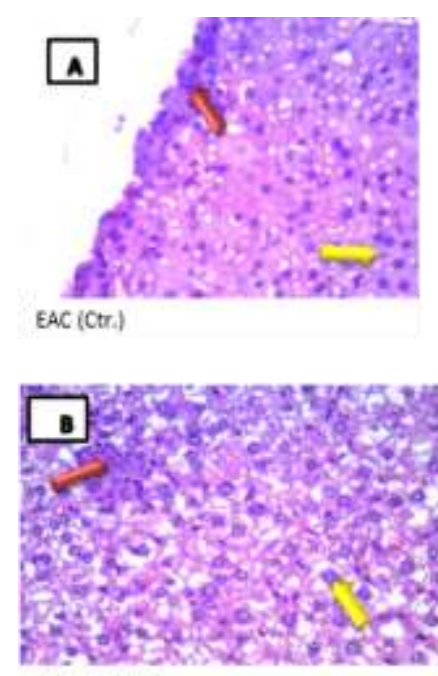

Hyperthermia

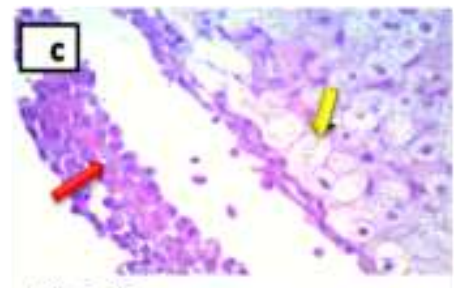

$100 \mathrm{mg} 2 \mathrm{SC}$

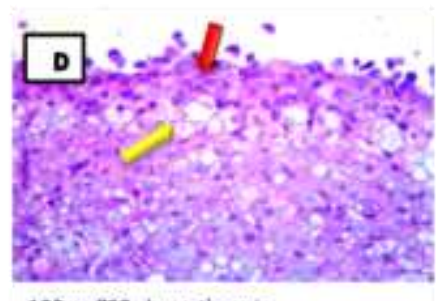

$100 \mathrm{mg}$ 25C+ hyperthermis

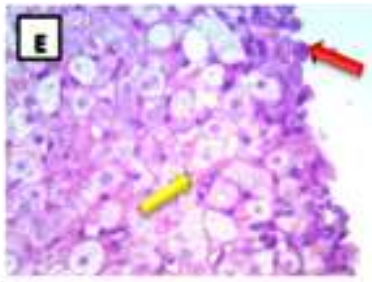

$300 \mathrm{mg} Z \mathrm{ZSC}$

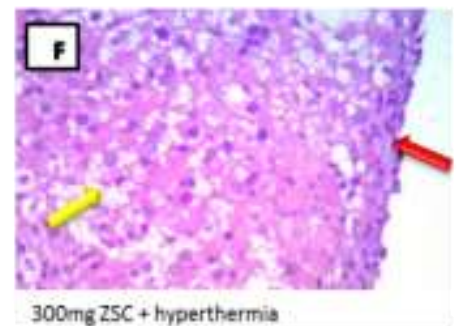

Figure 3:- Representative liver sections of mice 15 days after loading by EAC cells after different treatments. Stained by H\&E. 
Histological section of liver of EAC-bearing mice shows the proliferation of malignant cells on the surface of the liver (Figure 3.A; red arrow) and changes in liver cells as mentioned (yellow arrow). Figure 3.B shows section from liver in hyperthermia treated group showed marked hydropic degeneration of liver cells (yellow arrow). Residual malignant cells were forming islands within liver tissue (red arrow). Figure 3.D shows section of liver in low dose combination group. There is moderate effect of treatment appears as moderate decrease in tumor cells with few viable residual cells seen on liver surface showing large nuclei and infiltration of liver (red arrow). There is moderate hydropic degeneration of liver cells (yellow arrow). Figure 3.E shows section of liver from high dose treated group. There is moderate effect of treatment appears as moderate decrease in tumor cells with few viable residual cells seen on liver surface showing large nuclei and infiltration of liver (red arrow). There is marked hydropic degeneration of liver cells (yellow arrow). Figure 3.F shows section of liver in high dose combination treated group appear as marked decrease in tumor cells with only very few viable residual cells seen on liver surface (red arrow). There is marked hydropic degeneration of liver cells (yellow arrow). Figure 3.C shows section of liver in low dose treated group. There is no effect. Tumor cells are seen on liver surface seen as multiple layers with large nuclei and infiltration of liver (red arrow). There is marked hydropic degeneration of liver cells (yellow arrow).
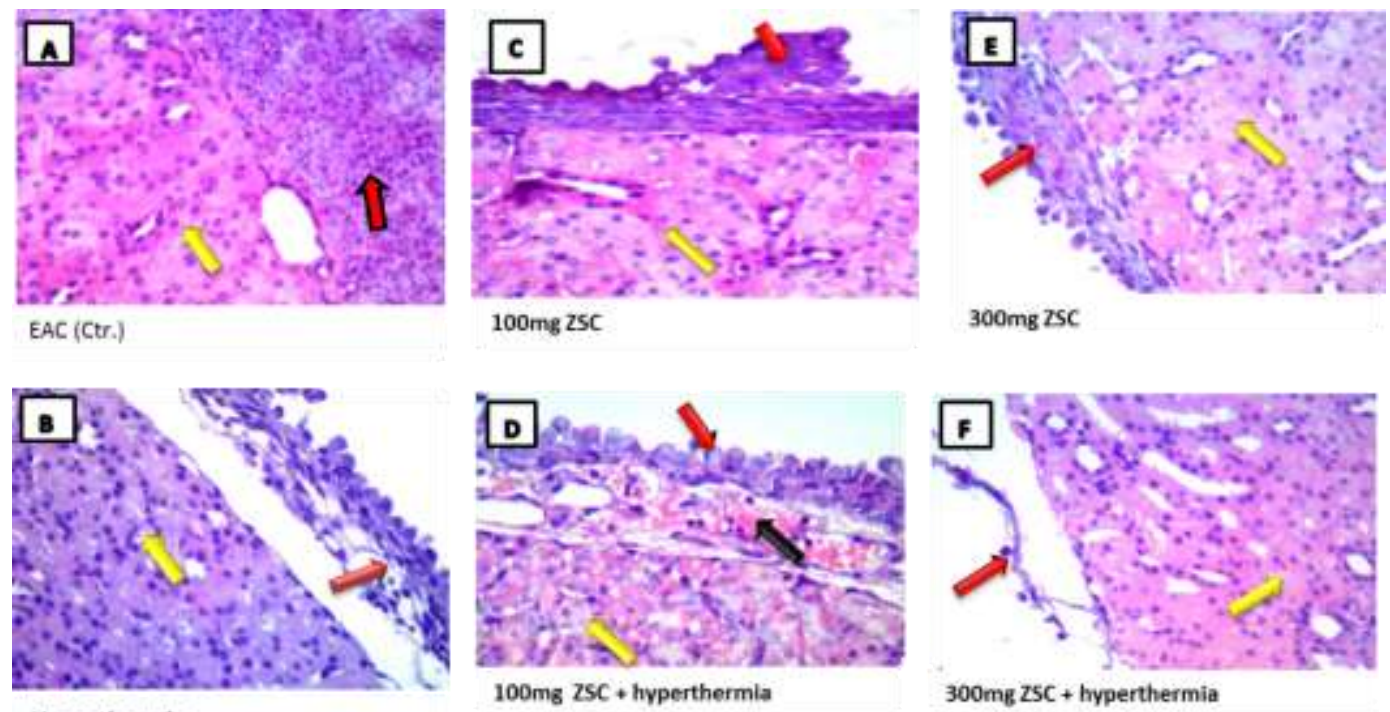

Hyperthermia

$100 \mathrm{mg} 25 \mathrm{C}+$ hyperthermia

$300 \mathrm{mg}$ ZSC + hyperthermia

Figure 4:- Representative kidney sections of mice, 15 days after loading by EAC cells after different treatments, stained by H\&E.

Figure 4.A shows a representative section of kidney of EAC-bearing mice which show marked proliferation of malignant cells at surface of kidney tissue showing marked cellularity and pleomorphism (red arrow), and kidney tissue showed moderate cloudy swelling of tubular epithelial cells as degenerative change and effect of tumor (Yellow arrow). Figure 4.B shows a section of kidney in hyperthermia treated group. There is moderate effect of therapy as regards tumor cells decreased in thickness and number with presence of necrotic cells (red arrow) with few residual changes in kidney tissue presented as mild hydropic degeneration of tubular epithelial cells (yellow arrow). Figure 4.D, shows a section of kidney from low dose combination group. There was moderate decrease in tumor cells with viable residual cells seen on kidney surface forming multiple layers with large hyperchromatic nuclei (red arrow). There is a marked congestion (black arrow) and cloudy degeneration of tubular epithelium (yellow arrow). At figure 4.E, section of kidney in high dose treated group which shows moderate effect of treatment appears as decrease in tumor cells with viable residual cells seen on kidney surface forming multiple layers with large hyperchromatic nuclei (red arrow). There is a moderate tubular cloudy swelling seen in kidney tissue (yellow arrow). Figure 4.F shows a representative section of the kidney from the high dose combination treated group where there is a marked effect of treatment appears as marked reduction in tumor cell number with only very few viable residual cells seen on kidney surface (red arrow). Sight tubular cloudy swelling is seen in kidney tissue (yellow arrow). Figure 4.C shows a section of kidney in low dose treated group There is no decrease in tumor cells on kidney surface forming multiple layers with large hyperchromatic nuclei (red arrow) and cloudy degeneration of tubular epithelium(yellow arrow). 


\section{Discussion:-}

Natural Products have been the most significant source of drugs and drug leads in the history. Their dominant role in cancer chemotherapeutics is clear with about $74 \%$ of anticancer compounds being either natural products, or natural product-derived. The biodiversity of the world provides a resource of unlimited structural diversity for bio prospecting by international drug discovery programs.

Ehrlich ascites carcinoma (EAC) is a transplantable, poorly differentiated malignant tumor and one of the experimental breast tumor model derived from spontaneous mouse adeno-carcinoma. Similar to other tumors developing in body cavities, EAC cells fill the peritoneal cavity by rapid division of cells, accumulation of a fluid named ascitic fluid and animal dies 17-18 days following EAC transplantation (Ulakoglu and Altun, 2004). EAC are used as ascites or a solid form for different purposes (Zeybek, 1996 and Okay, 1998). In ascitic form, they have been used as a transplantable murine tumor model to investigate the antitumor effect of several natural and synthetic chemical substances (Segura et al., 2001). Inoculation of EAC cells results in appearance of the ascitic fluid which is considered the direct nutritional source of the tumor cells (Gupta et al., $2004 \mathrm{a} \& \mathrm{~b}$ ). The accumulation of ascitic fluid in peritoneal cavity was either due to (1) a reduced lymphatic recovery system which is associated with the obstruction of the lymphatic by the tumor cells, (2) angiogenesis which detected in ascites tumor bearing peritoneal wall and (3) microvessels hyperpermeability of the peritoneal cavity (Fanasaka et al., 2002).

Presence of tumors in the human body or in experimental animals is known to affect many functions of the vital organs especially the liver and kidney (Deways, 1982). These tissues come in direct touch with the ascites. Hepatocytes are severely damaged in the animals with EAC cells (Ramadori et al., 1983). Liver and kidney toxicity induced during tumor growth may be due to the excessive production of ROS that leads to oxidative damage (Pal et al., 2005) and cytokines ( TNF $\alpha$ and IL- 6 ) produced by tumor growth (Lin and Karin, 2007). Borges et al., (2006) had observed that oxidative damage represented as increased lipid peroxidation and inhibition of GSH content, catalase and SOD activity, led to liver and kidney dysfunction.

In this study, treatment of EAC - bearing mice with ZSC or in combination with hyperthermia induce appreciated changes in the levels of either sGOT or sGPT compared with EAC group as a positive control. Results of the present study demonstrated that the liver activities of sGOT and sGPT had not been affected significantly, while EAC-load led to some liver dysfunction. On the other side, the albumin level had increased in all treated groups except in high dose combination treated group in which the Albumin level significantly decreased when compared with hyperthermia treated group. This finding is in agreement with Abd El- Aziz et al., (2014) who studied the inhibitory effects of Rosemary (Rosmarinusofficinalis L.) on Ehrlich ascites carcinoma in mice. The improvement of albumin levels after ZSC treatment may be due to the hepato protective activity of ZSC in EAC-bearing treated mice. These results are in line with these findings by Natesan et al., (2007) and Senthilkumar, (2008) who showed that the methanol extract of Careyaarborea bark (MECA) have a hepatoprotective activity from EAC-load in mice.

Urea and creatinine levels, which are considered as makers of kidney function (Robbins et al., 2001), revealed a negative effect of ZSC extract treatments on the kidney as indicated by significantly increase in high dose treated group, while creatinine level did not show significant changes. An elevation of urea may be attributed to an increase in nitrogen retention or excessive protein breakdown (Geraci et al., 1990). These alterations induced by toxic conditions, reflecting metabolic cellular dysfunction (Gaw et al., 2001).

Histopathological assay offers more evidence for improving the EAC-induced cytotoxicity by different treatments of ZSC or hyperthermia or combination. Treatment with combination between hyperthermia and high dose of ZSC showed marked decrease in tumor cells number with only very few viable residual cells seen on liver surface but still there was a marked hydropic degeneration of liver cells. In addition, treating EAC-bearing mice with combination between hyperthermia and high dose of ZSC shows marked effect of treatment appear as marked decrease in tumor cells with only very few viable residual cells seen on kidney surface, however slight tubular cloudy swelling seen in kidney tissue.

In conclusion, loading mice with EAC cells induce a hepatic and renal toxicity. The results of histopathological examination of liver and kidney tissues after treatments concludes that a marked effect in case of combination between hyperthermia and ZSC rather than hyperthermia or ZSC independently. 


\section{References:-}

1. Abalaka, M. E.; Mann, A. and Adeyemo, S. O. (2011). Studies on in-vitro antioxidant and free radical scavenging potential and phytochemical screening of leaves of Ziziphus mauritiana L. and Ziziphus spinachristi L. compared with Ascorbic acid. Journal of Medical Genetics and Genomics. 3(2): 28 - 34.

2. Abd El-Aziz, A. F.; Hefni, M. E. and Shalaby, A. M. (2014). Inhibitory effects of Rosemary (Rosmarinus officinalis L.) on Ehrlich ascites carcinoma in mice. International Journal of Current Research and Academic Review. 2 (9):330-357.

3. Adzu, B.; Amos, S.; Amizan, M. B. and Gamaniel, K. (2003). Evaluation of the antidiarrhoeal effects of Ziziphus spina-christi stem bark in rats. Acta Tropica, 87(2):245-250.

4. Borges, L. P.; Nogueria, C. W.; Panatieri, R. B.; Rocha, J. B. and Zeni, G. (2006). Acute liver damage induced by 2 - nitropropane in rats. Effect of diphenyle diselenide on antioxidant defence. Chemico-biological Interactions. 160 (2): $99-107$.

5. Cragg, G. M and Newman, D. J. (2000). Antineoplastic agents from natural sources: Achievements and future directions. Expert Opinion Investigational Drugs. 9 (12): 2783-2797.

6. Dewys, W. D. (1982). Pathophysiology of cancer cachexia: current understanding and areas for future research. Cancer Research. 42(2):721s- 725s.

7. Evans, W. C. 15th ed. London: Sounders; 2002. Trease and Evans Pharmacognosy. pp. 394-406.

8. Fanaska, T.; Haga, A.; Raz, A. and Nagase, H. (2002). Tumor autocrine motility factor induces hyperpermiability of endothelial and mesothelial cells leading to accumulation of ascites fluid. Biochemical and Biophysical Research Communications. 293 (1): 192 - 200.

9. Gaw, A.; Cowan, R.; O'Reilly, D.; Stewart, M. and SDhepherd, J. (2001). BioquimicaClinca. 2nd ed. Rio de Janeiro: GanabaraKoogan.

10. Geraci, J. P.; Jackson, K. L.; Mariano, M. S. and Michieli, B. M (1990). Kidney and lung injury in irradiated rats protected from acute death by partial -body shielding. Official Journal of the Radiation Research Society. 112(1), 95- 100.

11. Gupta, M.; Mazumder, U. K.; Kumar, R. S.; Sivakumar, T. and Vamis, M. L. M. (2004a). Antitumor activity and antioxidant status of Caesalpinia bunducella against Ehrlich ascites carcinoma in Swis albino mice. Journal of Pharmacological Sciences. 94: 177 - 184.

12. Gupta, M.; Mazumder, U. K.; Kumar, R. S. and Kumart , S. (2004b). Antitumor activity and antioxidant role of Bauhinia racemosa against Ehrlich ascites carcinoma in Swiss albino mice. Acta pharmacologica Sinica. 25 (8): $1070-1076$.

13. Kaur, R.; Kapoor, K. and Kaur, H. (2011). Plants as a source of anticancer agents. Journal of Natural Product and Plant Resources. 1 (1):119-24.

14. Lin, W. W. and Karin, M. (2007). A cytokine - mediated link between innate immunity, inflammation and cancer. The Journal of Clinical Investigation. 117(5): 1175-1183.

15. Mervat, M. A. and Gendy, E. L. (2010). In vitro, evaluation of medicinal activity of egyptian honey from different floral sources as anticancer and antimycotic infective agents. Journal of Microbial \& Biochemical Technology. 2(5): 118-123.

16. Natesan, S.; Badami, S.; Dongre, S. H. and Godavarthi, A. (2007). Antitumor activity and antioxidant status of the methanol extract of Careya arborea bark against Dalton's lymphoma ascites induced ascitic and solid tumor in mice. Journal of pharmacological sciences. 103(1): 12-23.

17. Ochwang'I, D. O.; Kimwele, C. N.; Oduma, J. A.; Gathumbi, P. K.; Mbaria, J. M. and Kiama, S. G. (2014). Medicinal plants used in treatment and management of cancer in Kakamega County, Kenya. Journal of ethnopharmacology. 151(3): 1040-1055.

18. Okay, H. G. (1998). Deneysel EAT Oluşturulan Fare Karaciğer Plazmasında Nitrik Oksit Metabolizmasının İncelenmesi. Yüksek Lisans Tezi. İstanbul Üniversitesi Sağlık Bilimleri Enstitüsü. Biyokimya ABD. İstanbul.

19. Pal, S.; Bhattacharyya, S.; Choudhuri, T.; Datta, G. K.; and SA, G. (2005). Amolioration of immune cell number depletion and potentiation of depressed detoxification system of tumor - bearing mice by curcumin. Cancer detection and prevention. 29(5): $470-478$.

20. Ramadori, G.; Lenzi, M.; Dienes, H. P. and Meyer zum Buschenfelde K. H. (1983). Binding properties of mechanically and enzymatically isolated hepatocytes for IgG and C3. Liver 3(6): 358-368.

21. Robbins, M. E.C.; O'Malley, Y.; Zhao, W.; Davis, C. S. and Bonsib, S. M. (2001). The role of the tubuleinterstitium in radiation-induced renal fibrosis. Official Journal of the Radiation Research Society. 155 (3):481- 489 . 
22. Segura, J. A.; Ruiz-Bellido, M. A.; Arenas, M.; Lobo, C.; Marquez, J. and Alonso, F. J. (2001). Ehrlich Ascites Tumor Cells Expressing Anti-Sense Glutaminase RNA Lose Their Capacity to Evade the Mouse İmmune System. International Journal of Cancer. 91 (3): 379-384.

23. Senthilkumar, N.; Badami, S.; Dongre, S. H. and Bhojraj, S. (2008). Antioxidant and hepatoprotective activity of the methanol extract of Careya arborea bark in Ehrlich ascites carcinoma-bearing mice. Journal of Natural Medicines. 62 (3): 336- 339.

24. Ta"ckholm, V. (1974). Students' flora of Egypt, 2nd ed. Egypt: Cairo University. p 888.

25. Tulp, M. and Bohlin, L. (2002). Functional versus chemical diversity: Is biodiversity important for drug discovery?. Trends in Pharmacological Sciences 23 (5): 225-31.

26. Ulakoglu, G. and Altun, S. (2004): The effects of epirubicin on proliferation and DNA synthesis of Ehrlich ascites carcinoma cells in vitro and in vivo. Biologia, Bratislava, 59 (6): 727-734.

27. Zeybak, S. O. (1996). Enuygun Ehrlich Ascites tumor modellerinin farkli soy ve cinsiyetteki farelerde gosterilmesi. Istanbul universitiesi saglik bilimleri enstitusu deney hayvanlari biyolojisi ve biyomedikal uygulama teknikleri el anabilim dali . yuksek lisans Taz ;. Istanbul. 